\title{
Adaptability and stability of Coffea canephora Pierre ex Froehner genotypes in the Western Amazon
}

\section{Marcos Santana Moraes $^{1}$ (D) Rodrigo Barros Rocha ${ }^{2 *}$ (D) Alexsandro Lara Teixeira ${ }^{2}$ Marcelo Curitiba Espindula ${ }^{2}$ Camila Andrade Silva ${ }^{3}$ Aureny Maria Pereira Lunz ${ }^{4}$}

${ }^{1}$ Programa de Pós-graduação em Biodiversidade e Biotecnologia, Rede de Biodiversidade e Biotecnologia da Amazônia Legal, Porto Velho, RO, Brasil.

${ }^{2}$ Centro de Pesquisa Agroflorestal de Rondônia, Empresa Brasileira de Pesquisa Agropecuária (Embrapa), 76815800, Porto Velho, RO, Brasil. E-mail: rodrigo.rocha@embrapa.br. "Corresponding author.

${ }^{3}$ Instituto Federal de Rondônia (IFRO) Ariquemes, RO, Brasil.

${ }^{4}$ Centro de Pesquisa Agroflorestal do Acre, Empresa Brasileira de Pesquisa Agropecuária (Embrapa), Rio Branco, AC, Brasil.

ABSTRACT: The development of Coffea canephora cultivars is based on the characterization of genotype $\times$ environment interaction, which is interpreted to quantify the differential behavior of clones at different cultivation sites. The objective of this research was to study the genotype $x$ environment interaction aiming to select clones of broad and specific adaptation to different environments of the Western Amazon. Twelve clones with hybrid characteristics of the botanical varieties Conilon and Robusta and four open pollinated clones, had their performance evaluated in comparison with four controls. The genotype $\times$ environment interaction was interpreted based on the environmental quality index, the nonparametric estimator of Lin and Binns, 1988 and on the dispersion of the centroid method. Effects of the genotypes, environment, and genotype $\times$ environment interaction were all significant $(p<0.01)$. The environmental quality index (Ij) classified three environments as favorable for coffee production. In terms of the Lin and Binn's estimator $(P)$, hybrid genotypes 16, 10, 13, 09 and 14 presented lower $P_{i}$ indices than others, and were classified as being more stable. Five clones of low adaptability, seven clones of specific adaptability to favorable or unfavorable environments and two clones of broad adaptability to all environments were identified interpreting the dispersion of the centroid method.

Key words: $G \times E$ interaction, genetic progress, Coffee.

Adaptabilidade e estabilidade de genótipos de Coffea canephora Pierre ex Froehner na Amazônia Ocidental

RESUMO: O desenvolvimento de novas cultivares de Coffea canephora fundamenta-se na caracterização do comportamento diferenciado dos clones em diferentes locais de cultivo. O objetivo deste trabalho foi estudar a interação genótipo x ambientes visando selecionar clones de adaptação ampla e específica à diferentes ambientes da Amazônia Ocidental. Doze clones com características híbridas das variedades botânicas Conilon e Robusta e quatro clones provenientes de polinização aberta tiveram seu desempenho avaliado em comparação com quatro testemunhas. Os métodos utilizados para quantificar a interação genótipo x ambientes foram o estimador não paramétrico de Lin \& Binns e a dispersão do método centroide. A análise de variância indicou que os efeitos de genótipos, de ambiente e da interação $G x$ A foram significativos $(p<0,01)$. O indice de qualidade ambiental (Ij) permitiu classificar três ambientes favoráveis em relação a sua contribuição para o desempenho das plantas. Os genótipos híbridos 16, 10, 13, 9 e 14 apresentaram menores índices de Pi, tendo sido ranqueados como mais estáveis, apresentando produtividade média superior ao desempenho das testemunhas. Cinco clones de baixa adaptabilidade, sete clones de adaptabilidade especifica a ambientes favoráveis ou desfavoráveis e dois clones de ampla adaptabilidade foram identificados interpretando a dispersão no plano do método centroide.

Palavras-chave: interação $G x A$, progresso genético, Coffea spp.

\section{INTRODUCTION}

Coffea canephora is an allogamous and self-incompatible species of coffee originating from low-altitude regions of the African continent, of which two botanical varieties are cultivated commercially (CUBRY et al., 2013). The botanical variety Conilon is characterized by producing smaller plants that are tolerant to a water deficit and susceptible to orange rust, while the botanical variety Robusta is characterized by plants with erect growth and larger fruits, less tolerance to a water deficit, and greater tolerance to orange rust (SOUZA et al., 2013; DAVIS et al., 2006).

The high vigor of the hybrids formed through the breeding of genetically divergent parents 
is a characteristic of this species (OLIVEIRA et al., 2018; MONTAGNON et al., 2008; ROCHA et al., 2014). In 2004 were conducted hybridizations between matrices of the botanical varieties Conilon and Robusta, aiming to obtain plants that associate the best traits of their parent botanical varieties within the hybrid vigor (TEIXEIRA et al., 2017).

Other studies have reported the occurrence of genotype $\times$ environment $(\mathrm{G} \times \mathrm{E})$ interactions during the evaluation of $C$. canephora genotypes. Significant $\mathrm{G} \times \mathrm{E}$ interactions were observed by MONTAGNON et al. (2000) when evaluating C. canephora hybrid clones in nine environments in the Ivory Coast. FERRÃO et al. (2008) also observed significant effects of the genotype $\times$ environment interaction in their evaluations of clones of botanical variety Conilon in two municipalities of the state of Espírito Santo, Brazil. BARBOSA et al. (2014) verified that early and intermediate cycle clones presented lower performance in the state of Rio de Janeiro, Brazil, compared to their performance when evaluated in the state of Espírito Santo (BRAGANÇA et al., 2001). Studies of $G \times E$ interactions test the hypothesis that plants change their performance when grown in different locations.

During the selection of plants, the identification of genotypes with broad and specific adaptability allows the effects of the genotype $x$ environment interaction to be explored (RAHN et al., 2018; ROCHA et al., 2015). Methods based on multivariate statistics allowed interpreting the adaptability and stability of several genotypes simultaneously, classifying them according to their performance (HAMAWAKI et al., 2015; ANDERSON, 2003). In the centroid method, results of performance evaluations are interpreted in a graphic dispersion based on the comparison of the evaluated plants with ideotypes, which are ideal reference plants of known behavior (ROCHA et al., 2005; NASCIMENTO et al., 2009).

Non-parametric methodologies, such as those of Lin and Binns (1988), have also been used to identify genotypes of broad or specific adaptability. The decomposition of the Lin and Binns estimator provided the information needed to recommend genotypes to specific environments, classified as favorable or unfavorable to coffee cultivation (CRUZ et al., 2012).

Therefore, the objective of this research was to study the genotype $\mathrm{x}$ environment interaction aiming to select clones of broad and specific adaptation to different environments of the Western Amazon.

\section{MATERIALS AND METHODS}

\section{Genetic material}

In 2004, targeted hybridizations were conducted between superior matrices of the botanical varieties Conilon and Robusta to obtain nine progeny sets of complete siblings. These progenies represented by 32 genotypes, arranged in 4 replicates of 8 plants, were evaluated during six harvests in the experimental field of the Embrapa Rondônia located in the city of Ouro Preto do Oeste, RO, Brazil (TEIXEIRA et al., 2017). Based on this evaluation, 12 genotypes that showed desirable characteristics of the botanical varieties Conilon and Robusta were selected to be further evaluated in different environments in the Western Amazon.

\section{Clonal competition assays}

In December 2012 and January 2013, five clonal competition assays were installed at different locations in the Western Amazon, as described below:

Assay \#1 (Ouro Preto do Oeste, RO). This assay was carried out in the experimental field of the Brazilian Agricultural Research Corporation, located at $10^{\circ} 43^{\prime} 55.3^{\prime \prime} \mathrm{S}$ and $62^{\circ} 15^{\prime} 23.2^{\prime \prime} \mathrm{W}$, at $245 \mathrm{~m}$ altitude. The climate of the municipality in which this assay was installed is of the "Aw" type of the Köppen classification system, which is defined as humid tropical with periods of drought during winter, and rainy during summer. The annual temperature varies from $21.2^{\circ} \mathrm{C}$ to $30.3^{\circ} \mathrm{C}$, with the highest temperatures occurring in the months of July and August. The annual precipitation is $1939 \mathrm{~mm}$ and the average air humidity is $81 \%$ (INMET, 1992).

Assay \#2 (Porto Velho, RO). This assay was evaluated in another experimental field belonging to the Brazilian Agricultural Research Company, located at $8^{\circ} 48^{\prime} 05.5^{\prime \prime} \mathrm{S}$ and $63^{\circ} 51^{\prime} 02.7^{\prime \prime} \mathrm{W}$, at $88 \mathrm{~m}$ altitude. The predominant climate of the region is rainy tropical with a dry winter, of type "Am" (Köppen), and with an average temperature of $26.0{ }^{\circ} \mathrm{C}$ and average annual precipitation of $2095 \mathrm{~mm}$. September is the hottest month of the year $\left(27.1^{\circ} \mathrm{C}\right)$, and May is the coldest one $\left(24.9^{\circ} \mathrm{C}\right)$ (INMET, 2009).

Assay \#3 (Ariquemes, RO). This assay was conducted at the Federal Institute of Rondônia, Ariquemes Campus. The local coordinates were $9^{\circ} 57^{\prime} 09,8$ 'S and $62^{\circ} 56 ' 53,7^{\prime} ' \mathrm{~W}$, at $128 \mathrm{~m}$ altitude. The predominant climate is the humid tropical type "Aw" (Köppen), with a well-defined dry season between June and August. Water deficit varies from 200 to $300 \mathrm{~mm} \mathrm{year}^{-1}$, and the annual average rainfall is $2181 \mathrm{~mm}$. The average temperature throughout the 
year is close to $25.4^{\circ} \mathrm{C}$, while September is the hottest month and July is the driest one (INMET, 2009).

Assays \#4 and \#5 (Rio Branco, AC). These two assays were conducted at Embrapa Acre, one with irrigation and one without irrigation. The local coordinates were $10^{\circ} 1 ' 30.98^{\prime \prime} \mathrm{S}, 67^{\circ} 42^{\prime} 21.77^{\prime \prime} \mathrm{W}$, at $180 \mathrm{~m}$ altitude. The predominant climate is the humid tropical type "Aw" (Köppen), with a well-defined dry season between June and August. The water deficit ranges from 50 to $100 \mathrm{~mm}_{\text {year }}{ }^{-1}$, and the annual average precipitation is $1998 \mathrm{~mm}$. The average temperature throughout the year is close to $24.9^{\circ} \mathrm{C}$, while October is the hottest month and July is driest one (INMET, 1992).

Soil, nutritional, cultural, and phytosanitary practices at each assay site were carried out according to the recommendations of the Production System for coffee cultivation in Rondônia (MARCOLAN, 2009).

\section{Experiments}

Plants used in the assays comprised twelve hybrid clones and four open pollinated clones, with an average coffee productivity above 70 bags ha ${ }^{-1}$ and resistance to orange rust. In addition, four clones of a cultivar adapted to tropical and low-altitude conditions, Conilon cv. BRS Ouro Preto, were used as controls (Table 1). The 20 treatments were conducted

Table 1 - Genetic composition and origins of the clones evaluated in the competition assays installed in five localities in the Western Amazon.

\begin{tabular}{|c|c|c|}
\hline Clone & Genotype & Origin \\
\hline 1 & BRS OPO 125 & Control \\
\hline 2 & BRS OPO 160 & Control \\
\hline 3 & BRS OPO 120 & Control \\
\hline 4 & BRS OPO 199 & Control \\
\hline 5 & Clone 453 & Open pollination \\
\hline 6 & Clone 657 & Open pollination \\
\hline 7 & Clone 636 & Open pollination \\
\hline 8 & Hybrid 193 & Open pollination \\
\hline 9 & Hybrid 9 & Encapa 03 x Robusta 640 \\
\hline 10 & Hybrid 10 & Encapa 03 x Robusta 2258 \\
\hline 11 & Hybrid 11 & Encapa 03 x Cpafro 194 \\
\hline 12 & Hybrid 12 & Encapa 03 x Robusta 2258 \\
\hline 13 & Hybrid 13 & Encapa 03 x Robusta 2258 \\
\hline 14 & Hybrid 14 & Encapa 03 x Robusta 640 \\
\hline 15 & Hybrid 15 & Encapa 03 x Robusta 2258 \\
\hline 16 & Hybrid 16 & Encapa03 x Robusta 1675 \\
\hline 17 & Hybrid 17 & Encapa 03 x Robusta 1675 \\
\hline 18 & Hybrid 18 & Robusta 640 x Cpafro 194 \\
\hline 19 & Hybrid 19 & Robusta 1675 x Cpafro 194 \\
\hline 20 & Hybrid 20 & Encapa 03 x Robusta 1675 \\
\hline
\end{tabular}

in a randomized block design, with three replicates of four plants per plot, in a space $3 \mathrm{~m} \times 1.5 \mathrm{~m}$ in size. Randomization restriction was performed in the field to maximize homogeneity within each block.

To estimate the productivity of different clones in terms of the number of processed coffee bags produced per hectare during the 2014/15, 2015/16, and 2016/17 seasons, coffee beans were harvested from each plot and weighed on an analytical balance. Subsequently, 3-kg samples were collected and dried on a Barcaça-type concrete terrace until reaching $13 \%$ humidity, thus obtaining the ratio of farm coffee to processed coffee. The productivity of $60-\mathrm{kg}$ processed coffee sacks per hectare was estimated as follows in eq. (1):

$P R O D=\frac{\left(\frac{c r}{q p}\right)}{60} * 2.222 *$ rend

where: $P R O D$ is the productivity of coffee in bags per hectare; $c r$ is the farm coffee production by plot; $q p$ is the number of plants in the plot; 2.222 is the number of plants per hectare; rend is the ratio calculated between processed and farm coffee produced, expressed as a decimal value; and 60 corresponds to the weight in kilograms of a bag of processed coffee.

\section{Quantification of the genotype $\times$ environment interaction}

The significance of the clonal effect in each environment on the productivity of processed coffee (bags $\mathrm{ha}^{-1}$ ) was tested individually for the 2014/15, 2015/16, and 2016/17 crops, according to the model described by CRUZ et al. (2012), as follows in eq. (2): $Y_{i j k}=m+G_{i}+B_{j}+E_{i j k}$ where: $Y_{i j k}$ refers to the observation of the $i^{\text {th }}$ genotype, in the $j^{i \text { th }}$ block, and in the $k^{\text {th }}$ repetition; $m$ is the experimental average; $G_{i}$ is the effect of the $i^{\text {th }}$ genotype (clone effect); $B_{j}$ is the $j^{\text {th }}$ block effect; and $E_{i j k}$ is the experimental error that affects all the observations made during the experiment. To test the homogeneity among the variances was used the Bartlett's test (CRUZ et al., 2012).

After verifying the homogeneity of variances of the data, a joint variance analysis was performed to quantify the effect of the $\mathrm{G} \times \mathrm{E}$ interaction, according to the model described by CRUZ et al. (2012) as follows in eq. (3):

$Y_{i j k}=m+G_{i}+B / A_{j k}+A_{j}+G A_{i j}+E_{i j k}$ where $Y_{i j k} \mathrm{e}$ refers to the observation of the $i^{\text {th }}$ genotype, in the $k^{\text {th }}$ block, and in $j^{\text {th }}$ environment; $m$ is the experimental average; $G_{i}$ is the effect of the $i^{\text {th }}$ genotype (clone effect); $B / A_{j k}$ is the $k^{\text {th }}$ block's effect 
within the $j^{\text {th }}$ environment; $\mathrm{A}_{\mathrm{j}}$ is the effect of the $j^{\text {th }}$ environment; $\mathrm{GA}_{\mathrm{ij}}$ is the effect of the interaction between the $i^{\text {th }}$ genotype and the $j^{\text {th }}$ environment ( $\mathrm{G} \times \mathrm{E}$ interaction effect); and $\mathrm{E}_{\mathrm{ijk}}$ is the experimental error. The genotypes were considered to have random effects, while the blocks and environmental effect were considered to be fixed.

To quantify the contribution of the different environments to the performance of the genotypes, the environmental quality index $\left(I_{\mathrm{j}}\right)$ was estimated based on EBERHART and RUSSEL (1966) as follows in eq. (4):

$$
I_{j}=\bar{y}_{j}-\bar{y}
$$

where $\mathrm{I}_{\mathrm{j}}$ is the environmental classification index; $\bar{y}$ is the general average of genotypes in the $j^{\text {th }}$ environment; and $\bar{y}$ is the overall average of genotypes in all environments. This index classifies environments that have an $I_{j}$ equal to or greater than zero as favorable, and those with a negative $I_{j}$ as unfavorable.

To quantify the adaptability and stability of the production of processed coffee by different clones in different environments, the estimator proposed by LIN and BINNS (1988) was interpreted as follows in eq. (5):

$$
P_{i}=\frac{\sum_{j=1}^{n}\left(X_{i j}-M_{j}\right)^{2}}{2 n}
$$

where $P_{i}$ is the estimated stability and adaptability of the $i^{\text {th }}$ genotype; $X_{i j}$ is the productivity of the $i^{\text {th }}$ genotype in the $j^{\text {th }}$ environment; $M_{j}$ is the maximum response observed among all genotypes in the $j^{\text {th }}$ environment; and $n$ is the number of environments. By estimating the Euclidean distance between the genotypes and the ideal plant of superior performance in all environments, the smaller estimates of Pi characterize the genotypes of higher adaptability. This estimator was interpreted by considering the decomposition of $P_{i}$ in favorable and unfavorable environments.

Stability and adaptability estimates were also obtained based on the centroid method by considering the data as vectors in relation to the maximum and minimum performances of the genotypes in each environment. Based on these vectors, ideal references, called centroids, were obtained using the minimum, average, and maximum performances of each of the genotypes in favorable and unfavorable environments (NASCIMENTO et al., 2009; ROCHA et al., 2005). The clones under evaluation were classified based on the Euclidean distance of each genotype from the known behavioral references (centroids), according to the model summarized in eq. (6):
$D_{i k}=\sqrt{\sum_{j=1}^{n}\left(X_{i j}-C_{i j k}\right)^{2}}$

where: $\mathrm{D}_{\mathrm{ik}}$ is the distance from the $i^{\text {th }}$ genotype to the $k^{\text {th }}$ centroid $(\mathrm{k}=1,2, \ldots \mathrm{n})$, with each genotype subsequently classified as follows: : I, high general adaptability; II, specific adaptability to favorable environments; III, specific adaptability to unfavorable environments; IV, little adapted; $\mathrm{V}$, high stability, low adaptability; VI, specific adaptability to favorable environments; and VII, specific adaptability to unfavorable environments. $\mathrm{X}_{\mathrm{ij}}$ is the productivity of the $i^{\text {th }}$ genotype in the $j^{\text {th }}$ environment and $\mathrm{C}_{\mathrm{ijk}}$ is the estimated productivity of the $k^{\text {th }}$ centroid in the $j^{\text {th }}$ environment.

The dispersion of the clones' performance to reference values was obtained using the principal component analysis. The dispersion of a matrix containing the coffee production in different environments, with a dimension equal to the number of evaluated genotypes plus seven additional lines corresponding to the reference points, was then calculated (HAIR et al. 2009).

\section{RESULTS AND DISCUSSION}

Results of individual analyses of variance (ANOVAs) were interpreted to quantify the experimental accuracy and management quality. Inheritability $\left(\mathrm{h}^{2}\right)$ and experimental coefficient of variation $\left(\mathrm{CV}_{\mathrm{e}}\right)$ values indicated that the experiments were well conducted in all environments (Table 2). The relationship between the highest and lowest variance observed in the municipalities of Ouro Preto do Oeste, RO, and Ariquemes, RO, was 4.3, indicating homogeneity among the variances according to Bartlett's test (CRUZ et al., 2012).

The environmental quality index $\left(I_{j}\right)$ was interpreted to classify environments in terms of their contribution to plant performance (EBERHART and RUSSEL,1966). Environments of Ouro Preto do Oeste and Rio Branco showed an average productivity of more than $50 \mathrm{bags} \mathrm{ha}^{-1}$, and were thus classified as favorable for coffee production (Table 2). The environments of Ariquemes and Porto Velho, which presented average productivities of 21.33 and 44.82 bags ha-1 ${ }^{-1}$ respectively, were classified as unfavorable (i.e. negative $I_{j}$ ). The higher effective acidity with low base saturation associated with the non-use of supplementary irrigation in these environments contributed to the lower productivity in those sites. According to the soil and climate zone classification of the state of Rondônia (RONDÔNIA, 2002), 
Table 2 - Main estimates from the results of experiments installed in different environments in the Western Amazon over the period from 2015 to 2017

\begin{tabular}{|c|c|c|c|c|c|c|}
\hline Environment & Prod (bags ha-1) & $\mathrm{I}_{\mathrm{j}}$ & AStrea & ASerror & $h^{2}$ & $\mathrm{CVe}_{(\%)}$ \\
\hline Ouro Preto do Oeste, RO & 50.54 & $\mathrm{I}_{\mathrm{j}}+$ & $1029.12^{* *}$ & 154.28 & 0.85 & 24.58 \\
\hline Porto Velho, RO & 44.82 & $\mathrm{I}_{\mathrm{j}-}$ & $1354.88^{* *}$ & 78.46 & 0.94 & 19.76 \\
\hline Ariquemes, RO & 21.33 & $\mathrm{I}_{\mathrm{j}^{-}}$ & $299.34^{* *}$ & 35.84 & 0.88 & 28.07 \\
\hline Rio Branco, $\mathrm{AC}^{1}$ & 54.4 & $\mathrm{I}_{\mathrm{j}}+$ & $736.29^{* *}$ & 48.6 & 0.93 & 12.81 \\
\hline Rio Branco, $\mathrm{AC}^{2}$ & 54.41 & $\mathrm{I}_{\mathrm{j}}+$ & $723.12^{* *}$ & 37.4 & 0.94 & 11.23 \\
\hline
\end{tabular}

Table shows the identification of environments, environmental quality index $\left(\mathrm{I}_{\mathrm{j}}\right)$, positive quality index $(\mathrm{I}+)$, negative quality index $(\mathrm{I}+)$, mean squares of treatments (AStrea) and error (ASerror), average productivity (Prod), heritability $\left(\mathrm{h}^{2}\right)$, and coefficient of environmental variation $(\mathrm{CVe}) .{ }^{* *}(\mathrm{P}<0,01)$ according to the F-test. ${ }^{1}$ irrigated experiment; ${ }^{2}$ non-irrigated experiment.

the municipalities of Ariquemes and Porto Velho present marginally edaphoclimatic conditions for coffee production, which makes the use of additional irrigation during the dry season necessary there.

The analysis of combined variance indicated that the effects of genotypes (clones), environments, and the $\mathrm{G} \times \mathrm{E}$ interaction were all significant according to the F-test $(\mathrm{p}<0.01)$ (Table 3 ). The significance of the $\mathrm{G} \times \mathrm{E}$ interaction indicated that different clones presented different performances among the environments, meaning that the clones did not maintain their relative performance in different soil and climate conditions.

Table 3 - Summary of the analysis of variance of the average productivity of processed coffee from three harvests evaluated at five localities in the Western Amazon.

\begin{tabular}{lcccc}
\hline SV & DF & SS & MS & F \\
\hline Blocks/Environments & 10 & 2805.83 & 280.58 & \\
Clones & 19 & 59617.1 & 3137.74 & $12.48^{* *}$ \\
Environments & 4 & 46088.6 & 11522.1 & $21.8^{* *}$ \\
Clones $\times$ & 76 & 19095.1 & 251.25 & $3.54^{* *}$ \\
Environments & 190 & 13473.8 & 70.91 & \\
Residuals & 299 & 141080 & & \\
Total & 45.1 & & & \\
Average & 18.67 & & & \\
CVe $_{(\%)}$ & & & & \\
\hline
\end{tabular}

SV: source of variation; DF: degrees of freedom; SS: sum of squares; MS: mean square; F: F-value of the analysis of variance; $\mathrm{CVe}_{(\%)}$ : coefficient of experimental variation. ${ }^{* *}(\mathrm{P}<0.01)$ according to the F-test.
MONTAGNON et al. (2000) reported that the degree of base saturation in acidic soils was one of the factors that most strongly influenced the performance of clones grown in different environments in the Ivory Coast. A significant genotype $\times$ environment interaction was also observed by FERRÃO et. al. (2008) in their evaluation of 40 Conilon coffee genotypes in lowaltitude environments in southeast Brazil. Different lineages of Coffea arabica also showed changes in their relative performance in different environments on the African continent (DEMISSIE et al., 2011; BEKSISA et al., 2018).

The $\mathrm{G} \times \mathrm{E}$ interaction limits the recommendation of clones with wide adaptability for coffee cultivation, since the interaction is characterized by changes in the relative performance of genotypes in different environments (CRUZ et al., 2012). Thus, in the selection of plants, clones with broad and specific adaptability may be used to maximize the potential gains obtained through plant selection.

The genotypic variance component made the greatest contribution to the total variance observed in the experiment, even compared to the variance components of the $\mathrm{G} \times \mathrm{E}$ interaction and the residual variance (Table 4). The intraclass correlation coefficient that measures the relation between the components of variance also indicates the predominance of the genotypic variance in the expression of this trait. The ratio between the coefficient of genetic variation $(\mathrm{CVg})$ and the experimental coefficient of variation (CVe) was 1.65 , which means that the experimental conditions are favorable to obtain gains with plant selection (CARIAS et al, 2016). While evaluating C. canephora genotypes with different maturation cycles, RODRIGUES et al. (2012) estimated $\mathrm{CVg} / \mathrm{CVe}$ values ranging from 0.79 
Table 4 - Genetic (G) and environmental (E) parameters of coffee productivity (averaged across three years) evaluated in 5 localities in the Western Amazon.

$\left.\begin{array}{lc}\hline \text { Genetic parameter } & \left.\begin{array}{c}\text { Processed coffee } \\ \text { production }(\text { bags ha }\end{array}{ }^{-1}\right)\end{array}\right)$

CVg: Coefficient of genetic variation; CVe: Coefficient of experimental variation.

to 1.31. In the evaluation of $C$. canephora genotypes in tropical conditions, RAMALHO et al. (2016) and SILVA et al. (2018) observed analogous $\mathrm{CVg} / \mathrm{CVe}$ ratios, with magnitudes of 1.72 and 1.5 , respectively.

Heritability estimates $\left(h^{2}\right)$ higher than 0.80 indicated predominance of the genotypic component in the expression of this trait (FERRÃO et al., 2008) (Table 4). These estimates depend on the genetic materials, experimental conditions and environmental effects (BIKILA et al., 2017, ROCHA et al., 2015). Estimates of heritability varying between 0.83 and 0.93 were observed by RODRIGUES et al. (2012) in their evaluation of processed coffee production in C. canephora genotypes with early, intermediate, and late maturation in Espírito Santo. In the same state, FERRÃO et al. (2008) also reported estimates higher than 0.8. RAMALHO et al. (2016), SILVA et al. (2018), and TEIXEIRA et al. (2017) observed heritability values of $0.94,0.84$, and 0.79 , respectively, in experiments conducted in the state of Rondônia.

The non-parametric methodology of LIN and BINNS (1988) is distinguished by its ease of interpretation and by the classification of genotype performance in environments, classified as either favorable or unfavorable for coffee production. This method is based on the Euclidean distance between the average productivity of a given genotype and the maximum productivity obtained in each environment; thus, clones with greater adaptability are those with the lowest estimates of $P_{i}$ based on this method.

The hybrid genotypes 9, 10, 13, 14, and 16 examined in this study presented relatively lower $P_{i}$ values than others (Table 5). These clones presented an average productivity of 61.5 bags ha $^{-1}$ in all environments, surpassing the performance of the control clones. TEIXEIRA et al. (2017), when studying progenies of the same parent plants from which these clones were selected, observed average productivities varying from 58.7 and 97.71 bags ha $^{-1}$ over the course of six harvests.

The hybrid clone 16 presented lower biennial oscillation and an overall high productive performance. It reached productivities of 92 and 106.5 bags ha $^{-1}$ in the third harvest in our Ouro Preto do Oeste and Porto Velho assays, respectively, and 113.4 and 106.1 bags ha $^{-1}$ in the second harvest in Rio Branco, with and without the use of irrigation, respectively. In the non-irrigated test conducted in the Ariquemes, the productivities of this clone

Table 5 - Average productivity over three years in terms of processed coffee bags per hectare of different clones during assays evaluated in 5 different environments in the Western Amazon, along with the ordering of clones and environments obtained by the method of Lin and Binns (1988).

\begin{tabular}{|c|c|c|c|c|c|}
\hline Clone & Genotype & Average & $\mathrm{Pi}_{\text {general }}$ & $\begin{array}{c}\mathrm{Pi} \\
(+)\end{array}$ & $\begin{array}{l}\mathrm{Pi} \\
(-)\end{array}$ \\
\hline 1 & BRS OPO 125 & 49.86 & 11 & 10 & 12 \\
\hline 2 & BRS OPO 160 & 38.16 & 14 & 13 & 15 \\
\hline 3 & BRS OPO 120 & 27.46 & 16 & 18 & 16 \\
\hline 4 & BRS OP0 199 & 52.87 & 7 & 11 & 3 \\
\hline 5 & Clone 453 & 28.26 & 17 & 17 & 17 \\
\hline 6 & Clone 657 & 28.69 & 18 & 16 & 19 \\
\hline 7 & Clone 636 & 20.21 & 20 & 19 & 20 \\
\hline 8 & Hybrid 193 & 44.18 & 12 & 12 & 11 \\
\hline 9 & Hybrid 09 & 57.40 & 4 & 5 & 5 \\
\hline 10 & Hybrid 10 & 63.59 & 2 & 2 & 4 \\
\hline 11 & Hybrid 11 & 40.85 & 13 & 14 & 10 \\
\hline 12 & Hybrid 12 & 49.32 & 10 & 6 & 14 \\
\hline 13 & Hybrid 13 & 63.06 & 3 & 3 & 2 \\
\hline 14 & Hybrid 14 & 54.02 & 5 & 7 & 6 \\
\hline 15 & Hybrid 15 & 54.64 & 6 & 4 & 8 \\
\hline 16 & Hybrid 16 & 69.45 & 1 & 1 & 1 \\
\hline 17 & Hybrid 17 & 37.91 & 15 & 15 & 13 \\
\hline 18 & Hybrid 18 & 20.16 & 19 & 20 & 18 \\
\hline 19 & Hybrid 19 & 50.57 & 9 & 8 & 9 \\
\hline 20 & Hybrid 20 & 51.37 & 8 & 9 & 7 \\
\hline
\end{tabular}

$\mathrm{Pi}_{\text {general }}$ : average square of the distance between the productivity of each clone and the maximum response of all clones in the same environment; $\operatorname{Pi}(+)$ : average square of the distance between clone productivity and the maximum response in favorable environments; $\mathrm{Pi}(-)$ : average square of the distance between clone productivity and the maximum response in unfavorable environments. 
were $23.4,44.2$, and 55.5 bags $\mathrm{ha}^{-1}$, in the first, second, and third year of production, respectively. Despite the lower overall productivity of this lastmentioned environment, which was limited by the lack of irrigation and higher soil acidity, the average productivity of this clone in this environment (41.1 bags $\mathrm{ha}^{-1}$ ) was still higher than the experimental average and the performance of the controls.

Productivities observed in this study were comparable to those reported by RAMALHO et al. (2016) when estimating the genetic progress within the selection of fifteen genotypes of the botanical variety Conilon. These authors reported productivities varying from 27.7 to $121.4 \mathrm{bags} \mathrm{ha}^{-1}$ in a preliminary clonal competition test, and from 16.6 to $133.1 \mathrm{bags} \mathrm{ha}^{-1}$ in a final competition test of clones. Clones selected by the coffee producers in the municipality of Nova Brasilândia, Brazil, showed an average productivity over the course of three harvests varying from 76 to 101 bags of processed coffee per hectare (ESPINDULA et al., 2017).

The centroid method was used to represent the genotypes of general and specific adaptability
(ROCHA et al., 2005) (Figure 1). In the dispersion plot, the hybrid genotypes 13 and 16 were close to the ideotype I, which represents the ideal plant with maximum productivity in all environments. Hybrid genotypes 9, 10 , and 15, as well as BRS Ouro Preto 125, showed specific adaptability to favorable environments, with similar classifications to ideotypes II and VI, and were characterized by maximum performance in favorable environments and minimum or average performance in unfavorable environments. Hybrid genotype 193 and BRS Ouro Preto 199 showed specific adaptability to unfavorable environments, while hybrid genotypes $12,14,19$, and 20 were similar to the ideotype $\mathrm{V}$, with average performance in all environments.

Genotype 16 showed good general adaptability, with a three-year average productivity of $69.5 \mathrm{bags} \mathrm{ha}^{-1}$ in all environments, 72.6 bags ha $^{-1}$ in favorable environments, and 64.8 bags ha ${ }^{-1}$ in unfavorable environments, corresponding to a selection gain (SG\%) of 53.9, 36.6, and $96.1 \%$, respectively (Table 6).

The average productivity of genotype 10, which showed good adaptability to favorable

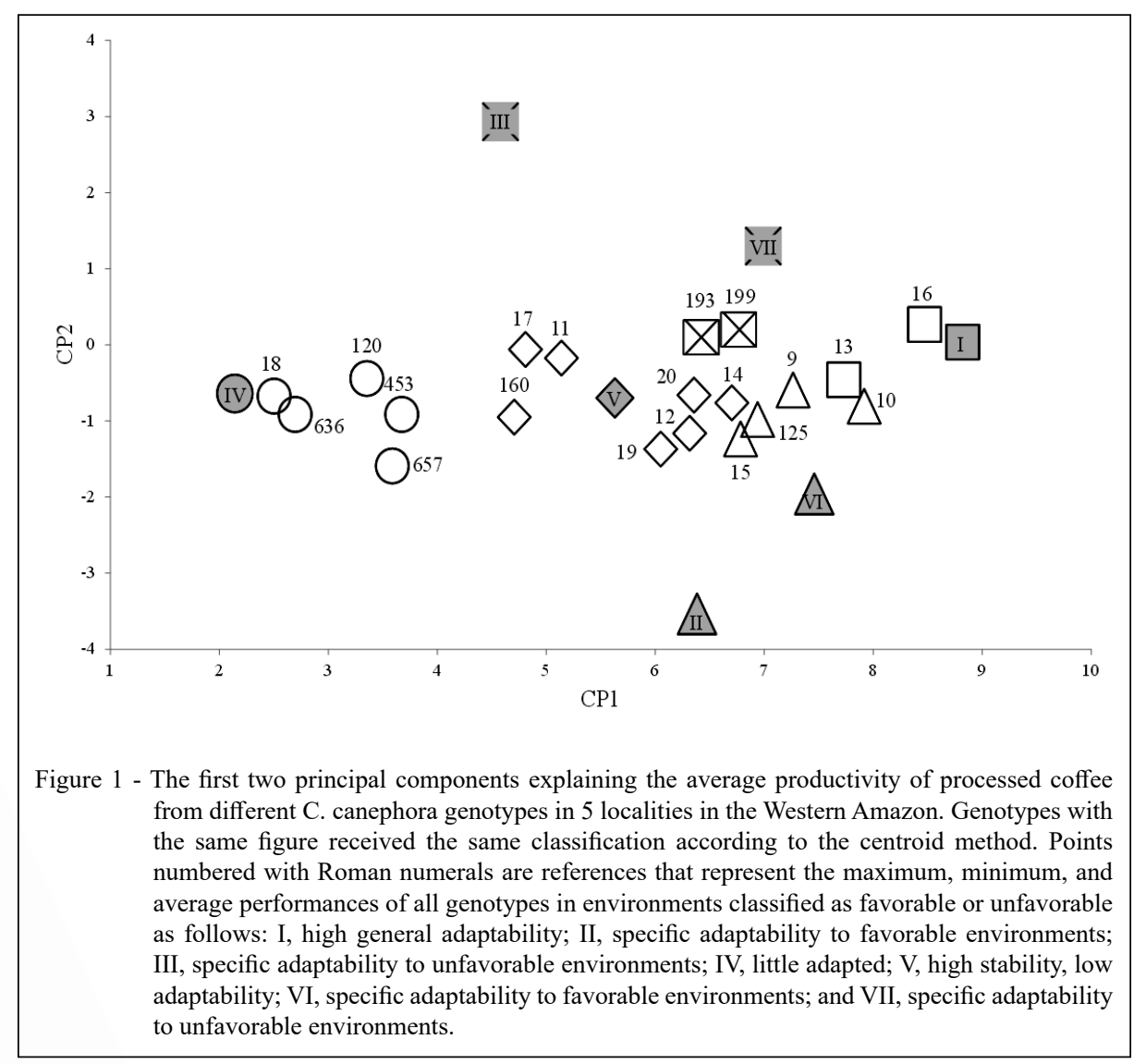

Ciência Rural, v.50, n.1, 2020. 
Table 6 - Estimates of genetic progress within the selection of clones with high adaptability (I), specific adaptability to favorable environments (II), and specific adaptability to unfavorable environments.

\begin{tabular}{|c|c|c|c|c|c|c|c|}
\hline Clone & Genotype & $\mathrm{GV}_{1}$ & $\mathrm{GV}_{2}$ & $\mathrm{GV}_{3}$ & $\mathrm{SG} \% 1$ & $\mathrm{SG} \%{ }_{2}$ & $\mathrm{SG} \% 3$ \\
\hline 1 & BRS OPO 125 & 49.86 & 61.02 & 33.12 & 10.54 & 14.87 & 0.13 \\
\hline 2 & BRS OPO 160 & 38.16 & 46.70 & 25.37 & -15.39 & -12.10 & -23.30 \\
\hline 3 & BRS OPO 120 & 27.46 & 31.77 & 20.99 & -39.12 & -40.20 & -36.55 \\
\hline 4 & BRS OPO 199 & 52.87 & 57.70 & 45.63 & 17.22 & 8.62 & 37.95 \\
\hline 5 & Clone 453 & 28.26 & 37.45 & 14.47 & -37.35 & -29.50 & -56.25 \\
\hline 6 & Clone 657 & 28.69 & 41.57 & 9.38 & -36.38 & -21.75 & -71.64 \\
\hline 7 & Clone 636 & 20.21 & 28.28 & 8.11 & -55.18 & -46.76 & -75.47 \\
\hline 8 & Hybrid193 & 44.18 & 49.32 & 36.48 & -2.04 & -7.16 & 10.29 \\
\hline 9 & Hybrid 09 & 57.40 & 66.39 & 43.92 & 27.27 & 24.97 & 32.79 \\
\hline 10 & Hybrid 10 & 63.59 & 74.30 & 47.51 & 40.99 & 39.87 & 43.65 \\
\hline 11 & Hybrid 11 & 40.85 & 44.91 & 34.77 & -9.43 & -15.45 & 5.12 \\
\hline 12 & Hybrid 12 & 49.32 & 62.07 & 30.20 & 9.35 & 16.84 & -8.69 \\
\hline 13 & Hybrid 13 & 63.06 & 70.54 & 51.84 & 39.82 & 32.79 & 56.73 \\
\hline 14 & Hybrid 14 & 54.03 & 62.60 & 41.16 & 19.79 & 17.85 & 24.45 \\
\hline 15 & Hybrid 15 & 54.64 & 66.32 & 37.13 & 21.15 & 24.84 & 12.25 \\
\hline 16 & Hybrid 16 & 69.45 & 72.56 & 64.84 & 53.99 & 36.58 & 96.05 \\
\hline 17 & Hybrid 17 & 37.91 & 42.12 & 31.58 & -15.96 & -20.71 & -4.51 \\
\hline 18 & Hybrid 18 & 20.16 & 25.94 & 11.49 & -55.31 & -51.18 & -65.26 \\
\hline 19 & Hybrid 19 & 50.57 & 61.78 & 33.75 & 12.12 & 16.30 & 2.05 \\
\hline 20 & Hybrid 20 & 51.38 & 59.12 & 39.75 & 13.91 & 11.29 & 20.20 \\
\hline Average & & 45.10 & 53.12 & 33.07 & & & \\
\hline
\end{tabular}

$\mathrm{GV}_{1}$ : genotypic value of processed coffee productivity in all environments; $\mathrm{GV}_{2}$ : genotypic value of processed coffee productivity in favorable environments; $\mathrm{GV}_{3}$ : genotype value of processed coffee productivity in unfavorable environments; $\mathrm{SG} \%$ : selection gain in all environments; $\mathrm{SG}_{2}$ : selection gain in favorable environments; $\mathrm{SG} \%{ }_{3}$ : selection gain in unfavorable environments.

environments, was 63.6 bags ha $^{-1}$ in all environments, 74.3 bags $^{-1}$ in favorable environments, and 47.5 bags $\mathrm{ha}^{-1}$ in unfavorable environments, corresponding to $\mathrm{SG} \%$ values of $41.0,40.0$, and $43.7 \%$, respectively. The genotype 199, with good adaptability to unfavorable environments, showed an average productivity of 52.9 bags ha $^{-1}$ in all environments, 57.7 bags $\mathrm{ha}^{-1}$ in favorable environments, and 45.6 bags $\mathrm{ha}^{-1}$ in unfavorable environments, corresponding to a SG\% of 17.2, 8.6, and 37.9, respectively (Table 6).The other genotypes were similar to the ideotypes IV and V, which were classified as being far from the ideotypes of both general and specific adaptability.

The selection of $C$. canephora genotypes should consider the average $\mathrm{SG} \%$ of several years, due to the high production oscillations of annual crops (MISTRO et al., 2004). Relevant gains by the selection of superior $C$. canephora genotypes in the state of Rondônia were pointed out by RAMALHO et al. (2016) who verified that an average gain of 25 bags $\mathrm{ha}^{-1}$ could be obtained through plant selection.
In addition, SILVA et al. (2018), while applying a selection intensity of $10 \%$ on 130 genotypes of the botanical varieties Conilon, Robusta, and natural hybrids, observed a genetic progress of $49.88 \%$, resulting in an average increase of 21.23 bags ha-1 over three years in the breeding population.

\section{CONCLUSION}

The significance of the $\mathrm{G} \times \mathrm{E}$ interaction indicated that the clones did not maintain their relative performance in different soil and climate conditions in five different environments of the Western Amazon. The centroid and Lin and Binns methods showed similar results to estimate the adaptability and stability of the different clones across the evaluated environments. Five clones of low adaptability $(18,636,120,453,657), 6$ clones of specific adaptability to favorable or unfavorable environments $(10,9,125,15,199,193)$, and 2 clones of broad adaptability $(16,13)$ were identified. Clone 
16 showed good general adaptability, and clones 10 and 199 showed specific adaptability to favorable and unfavorable environments, respectively.

\section{ACKNOWLEDGEMENTS}

The authors thank to the Conselho Nacional de Desenvolvimento Científico e Tecnológico $(\mathrm{CNPq})$ for the scholar ship grant. We also gratefully acknowledge the Consórcio Brasileiro de Pesquisa e Desenvolvimento do Café - CPC and the Coordenação de Aperfeiçoamento de Pessoal de Nível Superior (CAPES) for financial support.

\section{DECLARATION OF CONFLICT OF INTERESTS}

The authors declare no conflict of interest. The founding sponsors had no role in the design of the study; in the collection, analyses, or interpretation of data; in the writing of the manuscript, and in the decision to publish the results.

\section{AUTHORS' CONTRIBUTIONS}

All authors contributed equally for the conception and writing of the manuscript. All authors critically revised the manuscript and approved of the final version.

\section{REFERENCES}

ANDERSON, T. W. An Introduction to Multivariate Statistical Analysis. 3nd ed. John Wiley and Sons, 752p. 2003.

BARBOSA, D. H. G. S. et al. Adaptability and stability of conilon coffee in areas of high altitude. Genetics and Molecular Research, Ribeirão Preto, v.13, n.3, p.7879-7888, 2014. Available from: <https://www.geneticsmr.com>. Accessed: Nov. 5, 2019. doi: $10.4238 / 2014$

BEKSISA, L. et al. Genotype environment interaction and yield stability of Arabica coffee (Coffea arabica L.) genotypes. African Journal of Agricultural Research, v.13, n.4, p.210-219, 2018. Available from: <https://academicjournals.org/journal/AJAR $>$. Accessed: Nov. 5, 2019. doi: 10.5897/AJAR2017.12788.

BIKILA, B. A.; SAKIYAMA, N. S. Estimation of Genetic Parameters in Coffea canephora Var. Robusta. Advances in Crop Science and Technology, v.5, n.5, p.310, 2017. Available from: $<$ https://www.omicsonline.org $>$. Accessed: Nov. 5, 2019. doi: $10.4172 / 2329-8863.1000310$

BRAGANÇA, S. M. et al. Clonal varieties of Conilon coffee for the Espírito Santo State, Brazil. Pesquisa Agropecuária Brasileira v.36, n.5, p.765-770, 2001. Available from: <http://www.scielo.br>. Acessed: Nov. 5, 2019. doi:10.1590/S0100-204X2001000500006.

CARIAS, C. M. O. M. et al. Prediction of genetic gains by mixed models in conilon coffee progenies. Coffee Science, v.11, n.1, p.39-45, 2016. Available from: <www.coffeescience.ufla.br> Accessed: Nov. 5, 2019. doi: 10.25186/cs.v11i1.

CRUZ, C. D.,et al. Modelos biométricos aplicados ao melhoramento genético, v.4, Viçosa: Editora UFV, 2012.
CUBRY, P. et al. Global analysis of Coffea canephora Pierre ex Froehner (Rubiaceae) from the Guineo-Congolese region reveals impacts from climatic refuges and migration effects. Genetic Resources and Crop Evolution, v.60, n.2, p.483-501, 2013. Available from: <https://link.springer.com/journal/10722>. Accessed: Nov. 5, 2019. doi: 10.1007/s10722-012-9851-5.

DAVIS, A. et al. An annotated taxonomic conspectus of the genus Coffea (Rubiaceae). Botanical Journal of the Linnean Society, v.152, n.4, p.465 - 512, 2006. Available from: <http://dx.doi.org/1 0.1111/j.1095-8339.2006.00584.x>. Accessed: Nov. 5, 2019. doi: 10.1111/j.1095-8339.2006.00584.x.

DEMISSIE, M.; et al. Additive main effects and multiplicative interaction analysis of coffee germplasms from southern Ethiopia. SINET: Ethiopian Journal of Science, v.34, n.1, p.63-70, 2011. Available from: <https://www.ajol.info/index.php/sinet>. Accessed: Nov. 5, 2019.

EBERHART, S.A.; RUSSELL, W. A. Stability parameters for comparing varieties 1. Crop science, v.6, n.1, p.36-40, 1966. Available from: $<$ https://dl.sciencesocieties.org/publications/cs $>$. Accessed: Nov. 5, 2019. doi: 10.2135/cropsci1966.0011183X000600010011x.

ESPINDULA, M. C., et al. Café em Rondônia, In: Partelli, F, L, e Gontijo, I, (Ed,), CAFÉ CONILON: Gestão e Manejo com Sustentabilidade, Alegre, ES: CAUFES, p. 60-88, 2017.

FERRÃO, R. G. et al. Genetic parameters in Conilon coffee. Pesquisa Agropecuária Brasileira, v.43, n.1, p.61-69, 2008. Available from: <http://www.scielo.br $>$. Accessed: Nov. 5, 2019. doi: 10.1590/S0100-204X2008000100009

HAIR, J. F., et al. Análise multivariada de dados. 6 ed. Porto Alegre, Bookman, 2009. 688p.

HAMAWAKI, R. L. et al. Adaptability and Stability Analysis of Soybean Genotypes Using Toler and Centroid Methods. American Journal of Plant Sciences, v.6, n.09, p.1509, 2015. Available from: <http://www.scirp.org>. Accessed: Nov. 5, 2019. doi: 10.4236/ajps.2015.69150

INMET. Normais Climatológicas 1981 a 2010, Meteorologia, I, N, D, Brasília: INMET 2009.

LIN, C. S.; BINNS, M. R. A. superiority measure of cultivar performance for cultivar $\mathrm{x}$ location data. Canadian Journal of Plant Science, v.68, p.193-198, 1988. Available from: <https:// www.nrcresearchpress.com/loi/cjps>. Accessed: Nov. 5, 2019. doi: 10.4141/cjps2013-386.

MARCOLAN, A. L. Cultivo dos Cafeeiros Conilon e Robusta para Rondônia. Porto Velho: Embrapa Rondônia, 2009. 61p.

MISTRO, J. C. et al. Estimates of genetic parameters and expected genetic gains with selection in robust coffee. Crop breeding and applied biotechnology, v.4, n.1, 2004. Available from: $<$ https:// http://www.scielo. br>. Acessed: Nov. 5, 2019. doi: 10.12702/1984-7033.v04n01a14.

MONTAGNON, C. et al. Genotype-location interactions for Coffea canephora yield in the Ivory Coast. Agronomie, v.20, n.1, p.101-109, 2000. Available from: <http://www.speciation.net/>. Accessed: Nov. 5, 2019. doi: 10.1051/agro:2000110.

MONTAGNON, C. et al. Heterozygous genotypes are efficient testers for assessing between-population combining ability in the 
reciprocal recurrent selection of Coffea canephora. Euphytica, v.160, n.1, p.101-110, 2008. Available from: <https://link. springer.com>. Accessed: Nov. 5, 2019. doi: 10.1007/s10681007-9561-9.

NASCIMENTO, M. et al. Alteração no método centroide de avaliação da adaptabilidade genotípica. Pesquisa Agropecuária Brasileira, v.44, n.3, p.263-269, 2009. Available from: <http:// www.scielo.br>. Accessed: Nov. 5, 2019. doi: 10.1590/S0100204X2009000300007.

OLIVEIRA, L. N. L. et al. Selection of Coffea canephora parents from the botanical varieties Conilon and Robusta for the production of intervarietal hybrids. Ciência Rural, v.48, n.4, 2018. Available from: <http://www.scielo.br>. Accessed: Nov. 5, 2019. doi: 10.1590/0103-8478cr20170444.

RAHN, E. et al. Exploring adaptation strategies of coffee production to climate change using a process-based model. Ecological Modelling, v.371, p.76-89, 2018. Available from: <www.journals.elsevier.com>. Accessed: Nov. 5, 2019. doi: 10.1016/j.ecolmodel.2018.01.009.

RAMALHO, A. R. et al. Genetic gain in the productivity of processed coffee from the selection of clones of 'Conilon' coffee. Revista Ciência Agronômica, v.47, n.3, p.516-523, 2016 Available from: $<$ http://ccarevista.ufc.br $>$. Accessed: Nov. 5, 2019. doi: $10.5935 / 1806-6690.20160062$

ROCHA, R. B. et al. Evaluation of the centroid method for study of environment adaptability of clones of Eucalyptus grandis. Ciência Florestal, v.15, n.3, p.255-266, 2005. Available from: $<$ https:// periodicos.ufsm.br/cienciaflorestal > . Accessed: Nov. 5, 2019. doi: 10.5902/198050981863.
ROCHA, R. B. et al. Caracterização e uso da variabilidade genética de banco ativo de germoplasma de Coffea canephora Pierre ex Froehner. Coffee Science, v.8, n.4, p.478-485, 2014. Available from: <www. coffeescience.ufla.br $>$. Accessed: Nov. 5, 2019. doi: 10.25186/cs.v8i4.

ROCHA, R. B. et al. Adaptability and stability of Coffea canephora coffee bean yield. Ciência Rural, v.45, n.9, p.15311537, 2015. Available from: <http://www.scielo.br>. Accessed: Nov. 5, 2019. doi: $10.1590 / 0103-8478 \mathrm{cr} 20141554$.

RODRIGUES, W. N. et al. Genetic parameters estimation in groups of Conilon coffee clones, Coffee Science, v.7, n.2, p.177-186, 2012. Available from: <www.coffeescience.ufla.br $>$. Accessed: Nov. 5, 2019. doi: 10.25186/cs.v7i2.308.

RONDÔNIA (Estado). Secretaria Estadual de Planejamento. Zoneamento Sócio-Econômico-Ecológico do Estado de Rondônia. Porto Velho: Planafloro, 2002.

SILVA, D. O. et al. Genetic progress with selection of Coffea canephora clones of superior processed coffee yield. Ciência Rural, v.48, n.3, 2018. doi: 10.1590/0103-8478cr20170443.

SOUZA, F. F. et al. Molecular diversity in Coffea canephora germplasm conserved and cultivated in Brazil. Crop breeding and applied biotechnology, v.13, n.4, p.221-227. 2013. Available from: <http://dx.doi.org/10.1590/S1984-70332013000400001>. Accessed: Nov. 5, 2019. doi: 10.1590/S1984-70332013000400001.

TEIXEIRA, A. L. et al. Performance of intraspecific hybrids (Kouillou x Robusta) of Coffea canephora Pierre, African Journal of Agricultural Research, v.12, n.35, p.2675-2680, 2017. Available from: <https://academicjournals.org/journal/AJAR>. Accessed: Nov. 5, 2019. doi: 10.5897/AJAR2017.12446. 